\title{
Analysis Symmetrical Blade Propeller Performance for Jalapatih 3 Ship Using CFD
}

\author{
Edi Jadmiko ${ }^{1}$, Tony Bambang Musriyadi ${ }^{2}$, Abdi Sauqi Akram ${ }^{3}$ \\ (Received: 24 August 2020 / Revised: 09 September 2020 / Accepted: 10 December 2020)
}

\begin{abstract}
Solar Sport One is a prestigious competition held annually in the Netherlands. The competition focuses on innovation, technology, and sustainable energy. Based on the experience/participation of Marine Solar Boat Team (MSBT) ITS in Event Solar Sport One 2018 using Jalapatih 3 vessel, then researched the propulsion system especially propeller for use in the next Solar Sport One event. This paper is done research using an opensource program called Openprop to design a propeller using numerical calculations for the ship Jalapatih 3. The research is conducted in several phases, where our initial stage of designing and counting numerically uses Openprop and comparing the calculation results with CFD simulation results as Performance analysis of the selected propeller. From a propeller model that has been designed, Fortescue Blade Propeller has not been able to push the ship Jalapatih 3 at 16 knots and the result of the comparison, gained the difference of Thrust $J=1.4 \mathrm{of} 22.063 \mathrm{~N}$ while Torque value has a difference of $2.35 \mathrm{Nm}$.
\end{abstract}

Keywords-CFD, jalapatih 3, propeller, solar sport one.

\section{INTRODUCTION}

S lar Sport One (SSO) is a competition in the Netherlands. The competition is on innovation, technology, and sustainable energy. The competition is attended by students and professionals from all over the world.

The race was first participated by its Marine Solar Boat (MSBT) Team in 2014 using Jalapatih 1. As the pioneer of the first solar-powered ship in Indonesia, the MSBT team participated in this most prestigious race. The latest innovation from its current MSBT team is the Jalapatih 3 ship. The ranking earned in this race in 2018 is the 3rd Top Speed Record SSO 2018 with a speed of $23.5 \mathrm{~km} / \mathrm{h}$. This achievement is still very far compared to other teams.

Based on the experience of the participation, there are many evaluations and team development plans to compete with better performance. the thing to note is the propulsion system on Jalapatih ships that are still lacking in terms of research. Especially on propellers. The propeller owned by the current team is still not able to drive Jalapatih 3 at a speed of $30 \mathrm{~km} / \mathrm{h}$. These speed parameters are key for its MSBT team to win the next SSO. In this paper, the authors conducted performance research from symmetrical blade propeller to Jalapatih 3 using CFDs.

The basis of this research is to find out the efficiency of the propeller model in the design. To test the performance of the propeller model, the Open Water Test or propeller test uses the CFD program to determine the value of Thrust and Torque. Both values are used to calculate the coefficient thrust (KT), coefficient torque

Edi Jadmiko, Department of Marine Engineering, Institut Teknologi Sepuluh Nopember, Surabaya 60111, Indonesia. E-mail: e.djatmiko@yahoo.com

Tony Bambang Musriyadi, Department of Marine Engineering, Institut Teknologi Sepuluh Nopember, Surabaya 60111, Indonesia. Email: tobac@its.ac.id

Abdi Sauqi Akram, Department of Marine Engineering, Institut Teknologi Sepuluh Nopember, Surabaya 60111, Indonesia. E-mail: kikiakram5@gmail.com
(KQ), and advanced speed coefficient ( $\mathrm{J}$ ) values. These three coefficients can be defined through equations as follows:

$$
\begin{aligned}
& K T=\frac{T p r o p}{\rho x n^{2} x D^{4}} \\
& K Q=\frac{Q}{\rho x n^{2} x D^{5}} \\
& \eta O=\frac{J x N T}{2 \pi x Q Q} \\
& l=\frac{V A}{n x D}
\end{aligned}
$$

where:

Tprop $=$ Thrust Propeller $(\mathrm{N})$

Qprop $=$ Torque Propeller $(\mathrm{Nm})$

$\mathrm{KT} \quad=$ Thrust Coefficient

KQ $=$ Torque Coefficient

$\mathrm{N} \quad=$ Rotation of propeller (rps)

$\mathrm{D}=$ Diameter of Propeller $(\mathrm{m})$

$\mathrm{Va}=$ Advanced Speed $(\mathrm{m} / \mathrm{s})$

$\mathrm{P} \quad=$ Density of Fluid $(\mathrm{kg} / \mathrm{m})$

\section{METHOD}

This research uses Computational Fluid dynamics simulations and should also conform to the research methodology. Here are the steps:

\section{A. Literature Studies}

Looking for literature studies from several reference sources related to propeller design using numerical calculations replicated using open-source application Openprop.

1) The Meaning of propeller Propeller is an important part of the propulsion system onboard. The working principle of the propeller is to produce thrust by rotating and sucking the flow of fluid. Various types of propellers have been developed according to the ship's function. Currently, the development of the propeller has many including A-series, B-series, 
C-series, K-series, Surface Piercing Propeller and so on. Geometry Propeller.

2) The geometry of the propeller is part of the propeller itself. If the geometry of the propeller is damaged, it lowers the performance of the propeller itself.

3) Openprop V3.3.4
OpenProp is an open-source program that can be used for the design, analysis, and fabrication of optimized propellers and horizontal axis turbines. [4]

The numerical method of this application uses the Lifting Line Theory. In this study, we used this open-source program, OpenProp, which is operated with MATLAB

\begin{tabular}{|c|c|c|c|c|c|c|c|c|c|c|c|}
\hline \multicolumn{11}{|l|}{ ApenProp } & \multirow{2}{*}{$-\quad \square \quad \times$} \\
\hline \multicolumn{11}{|l|}{ Single Design } & \\
\hline \multicolumn{2}{|l|}{ Specifications } & \multicolumn{6}{|c|}{ Blade Design Values } & \multicolumn{3}{|c|}{ Inflow Profile Values } & \multirow{5}{*}{$\begin{array}{l}\text { Options } \\
\text { O Propeller } \\
\text { Turbine } \\
\square \text { Hub } \\
\square \text { Chord optimiza... } \\
\square \text { Viscous forces }\end{array}$} \\
\hline Number of blades: & 2 & $r / R$ & $\mathrm{c} / \mathrm{D}$ & $\mathrm{Cd}$ & to/D & Skew & $\mathrm{Xs}_{\mathrm{s}} / \mathrm{D}$ & r & Va/vs & Vt/Vs & \\
\hline Rotation speed & 412.5 & 0.2 & 0.07 & 0.008 & 0.025 & 0 & 0 & & & & \\
\hline Rotor diameter (m): & 0.7 & 0.26 & 0.0833 & 0.008 & 0.0235 & 0 & 0 & & & & \\
\hline Required thrust $(\mathbb{N})$ : & 33 & 0.3 & 0.09 & 0.008 & 0.022 & 0 & 0 & & & & \\
\hline \multirow{2}{*}{$\begin{array}{l}\text { Ship speed }(\mathrm{m} / \mathrm{s}) \text { : } \\
\text { Hub diameter }(\mathrm{m}) \text { : } \\
\text { Fluid density } \\
\text { \# radial panels: } \\
\text { \# chordwise }\end{array}$} & 2.572 & 0.36 & 0.099 & 0.008 & 0.0205 & 0 & 0 & & & & \multirow{3}{*}{$\begin{array}{l}\square \text { optimization pl... } \\
\square \text { Geometry plots } \\
\square \text { Performance c... }\end{array}$} \\
\hline & 0.102 & 0.4 & 0.1045 & 0.008 & 0.019 & 0 & 0 & & & & \\
\hline \multirow{5}{*}{$\begin{array}{l}\text { Fluid density } \\
\text { \# radial panels: } \\
\text { \# chordwise }\end{array}$} & 1000 & 0.5 & 0.113 & 0.008 & 0.0175 & 0 & 0 & & & & \\
\hline & 20 & 0.6 & 0.1129 & 0.008 & 0.016 & 0 & 0 & & & & \multirow{2}{*}{$\begin{array}{l}\text { Airfoil type } \\
\text { Meanline type: }\end{array}$} \\
\hline & 20 & 0.7 & 0.1081 & 0.008 & 0.0145 & 0 & 0 & & & & \\
\hline & & 0.8 & 0.0968 & 0.008 & 0.013 & 0 & 0 & & & & $\begin{array}{l}\text { NACA a }=0.8 \vee \\
\text { Thickness type: }\end{array}$ \\
\hline & & 0.9 & 0.075 & 0.008 & 0.0115 & 0 & 0 & & & & NACA 65A010 $\checkmark$ \\
\hline \multicolumn{2}{|c|}{ Ducted Propeller } & \multicolumn{7}{|c|}{ Non-dimensional Parameters } & \multicolumn{3}{|l|}{ Tools } \\
\hline \multirow{3}{*}{$\begin{array}{l}\text { Thrust Ratio: } \\
\text { Duct section drag } \\
\text { duct D / prop D: }\end{array}$} & 1 & \multirow{3}{*}{\multicolumn{3}{|c|}{$\begin{array}{l}J=V / n D=0.534442 \\
L=\text { omega } R / V=5.87827\end{array}$}} & \multirow{3}{*}{\multicolumn{3}{|c|}{$\begin{array}{l}C T= \\
K T=T /\left(\left(\operatorname{ro}^{*} \cap^{\wedge} 2^{2} D^{\wedge} 4\right)=\right.\end{array}$}} & 0.025924 & \multirow{2}{*}{\multicolumn{2}{|c|}{ Filename }} & \multirow[t]{2}{*}{ DefauttPropeller } \\
\hline & 0.008 & & & & & & & 0.002907 & & & \\
\hline & 1 & & & & & & & & Load & Save & Run OpenPr... \\
\hline
\end{tabular}

Figure. 1. OpenProp V3.3.4

The first Step, to input several values such as:
a. The number of Blades
b. Rpm
c. Propeller Diameter
d. Thrust Value
e. Ship speed
f. Diameter Hub

\section{B. Data Collection}

Collection of primary and secondary data for this research and to determine the primary dimensions of the propeller be designed. The data is in the form of Jalapatih 3, RPM propeller, thrust deduction factor, and wake fraction value.

\section{Calculation of Propeller Using Openprop}

To run the Openprop program, a MATLAB application is required. The results of the calculation use Openprop in the form of geometry propeller, KT value, $\mathrm{KQ}$, and propeller efficiency.

\section{Simulation Using CFD}

Numeric calculation data is then simulated using CFDs resulting in Thrust and Torque values to calculate $\mathrm{KT}$, KQ, and Efficiency coefficient values using equations (1), (2), and (3).

\section{RESULTS AND DISCUSSION}

1) Data Collection

In designing propeller designs, we need the ship's main data, namely general arrangement, principle dimension, and ship Resistance.

Then a prisoner simulation was conducted using CFDs with the Numeca FineMarine app. The results of this simulation will be conducted at a speed of 12 knots to 17 knots. The simulation results can be seen in figure 3 and table 1 . 


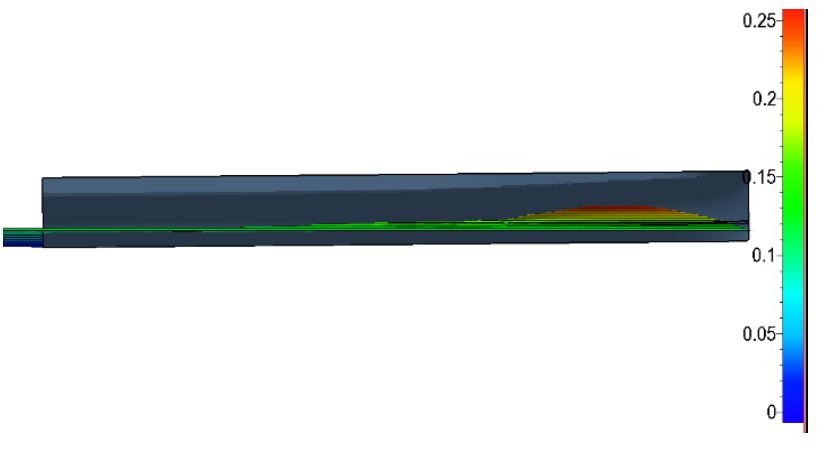

(a)

(b)
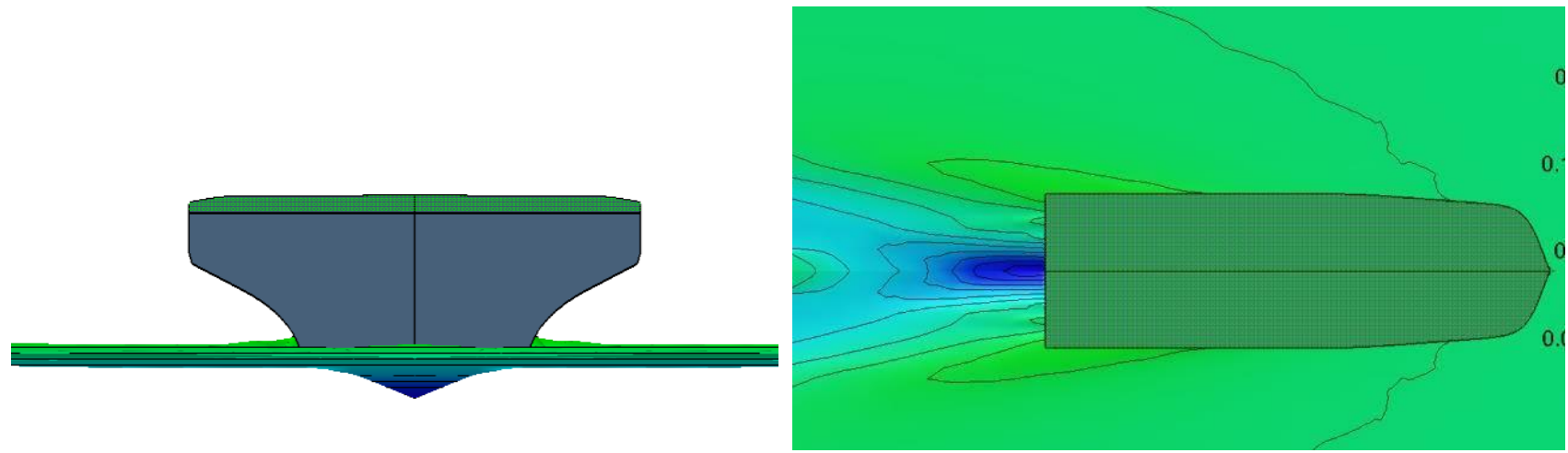

(c)

(b)

Figure. 2. Result of CFD simulation. (a) Side View, (b) Front view, (c) Back view, (d) Top view

TABLE 1.

RESULT OF SHIP RESISTANCE WITH CFD

\begin{tabular}{cc}
\hline $\begin{array}{c}\text { Speed } \\
(\text { knot })\end{array}$ & $\begin{array}{c}\text { Resistance } \\
(\mathrm{N})\end{array}$ \\
\hline 12 & 206.5416 \\
13 & 240.092 \\
14 & 277.5114 \\
15 & 317.368 \\
16 & 338.954 \\
17 & 406.08 \\
\hline
\end{tabular}

In table 1, prisoners are obtained using simulations. Prisoner data at a speed of 16 knots is $338,954 \mathrm{~N}$ at a sea margin of $0 \%$.

\section{2) Numeric Analyzing with OpenProp}

The data required in analyzing numerical calculations is the data of the test results of Jalapatih 3. The data can be viewed in table 1. once the data is found, it can be done to calculate the thrust $(\mathrm{T})$ value needed by the propeller to be able to push the ship. The value of prisoners used is $338,954 \mathrm{~N}$ at a speed of 16 knots and the thrust deduction factor is 0.2929 . Using the $\mathrm{T}$ value can be done using equations:

$$
\mathrm{T}=\frac{\mathrm{RT}}{\mathbb{[ 1}-\mathrm{t})}
$$

Where,

$$
\begin{array}{ll}
\mathrm{T} & =\text { Thrust Propeller }(\mathrm{N}) \\
\mathrm{RT} & =\text { Ship Resistance }(\mathrm{N}) \\
\mathrm{t} & =\text { thrust deduction factor }
\end{array}
$$

So with the data in table 1 can be done calculating thrust value at a speed of 16 knots. Furthermore, the data that has been obtained is applied to Openprop accompanied by several provisions such as RPM value according to the gearbox, propeller diameter, and others. Propeller design using Openprop results in symmetrical blade propeller performance for 3 leaves. 


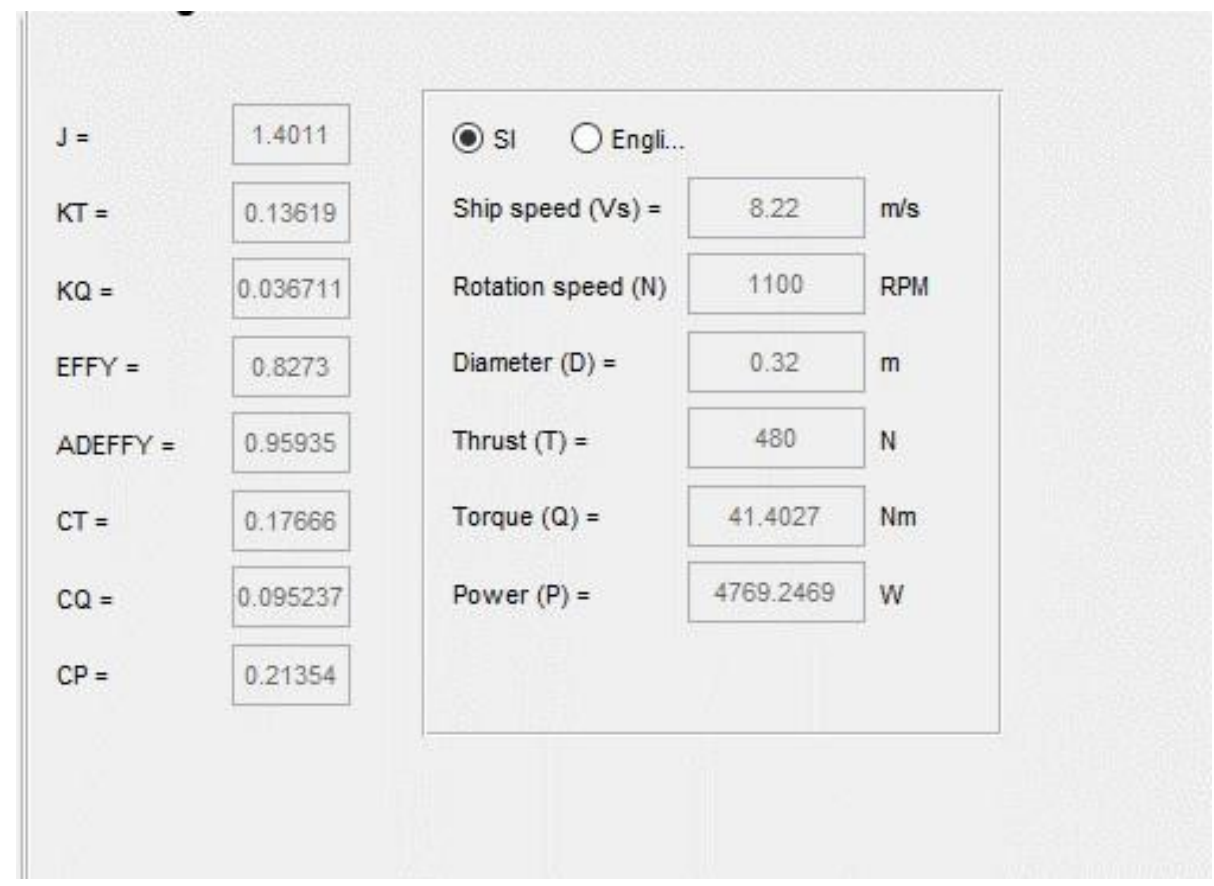

Figure. 3. Result of OpenProp calculation

From the calculation using Openprop produced torque value of $41.4027 \mathrm{Nm}$ and Thrust value of $480 \mathrm{~N}$. in figure 4.2 can be seen the resulting efficiency value is quite large which is 0.8273 . besides, an advanced Coefficient of J (1.4011) is generated, a KT (Thrust
Coefficient) value of 0.13619 and a KQ (Torque Coefficient) value of 0.036711 .

From the calculation results, Openprop also found an Open Water Test diagram that shows the performance of the propeller that has been designed.

\section{OPEN WATER SYMMETRICAL BLADE 3 DAUN}

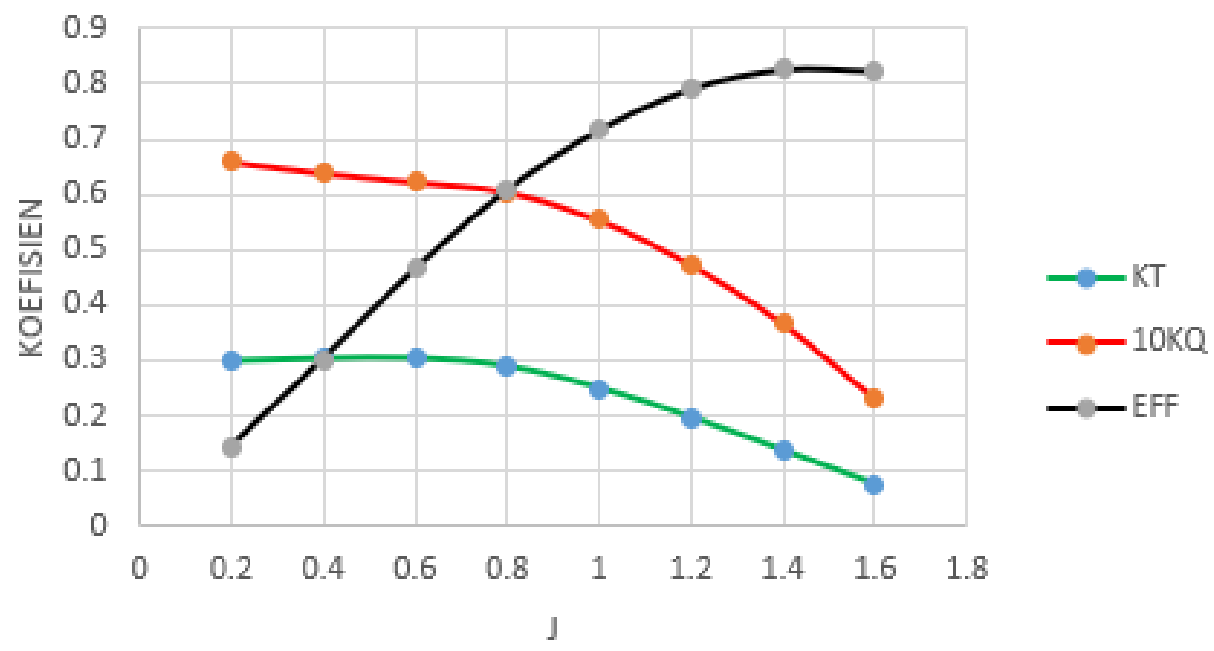

Figure. 4. Open water diagram using OpenProp

3) 3D Model Creation

In this study, the creation of 3D models used coordinates - curve coordinates produced by Openprop and used Solidwork applications and also to ensure that the model was solid. Then, the file is exported into Parasolid form before being simulated. 


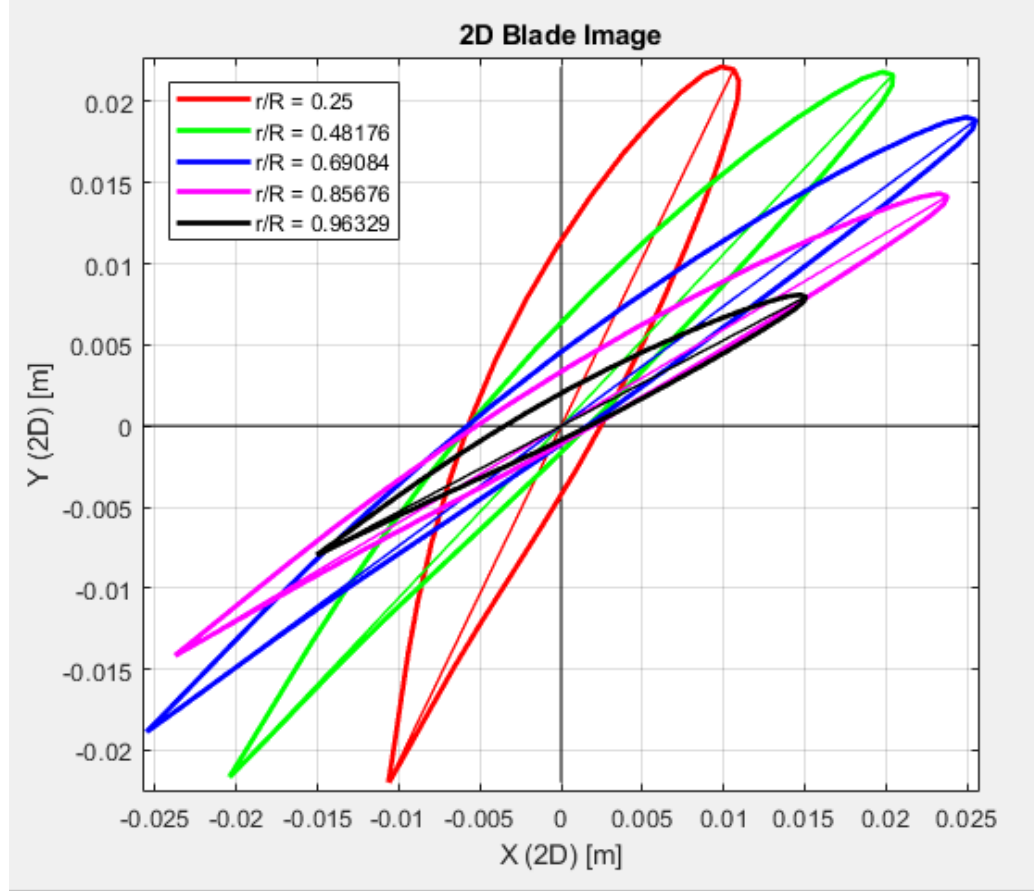

Figure. 5. Result of 2D symmetrical blade propeller
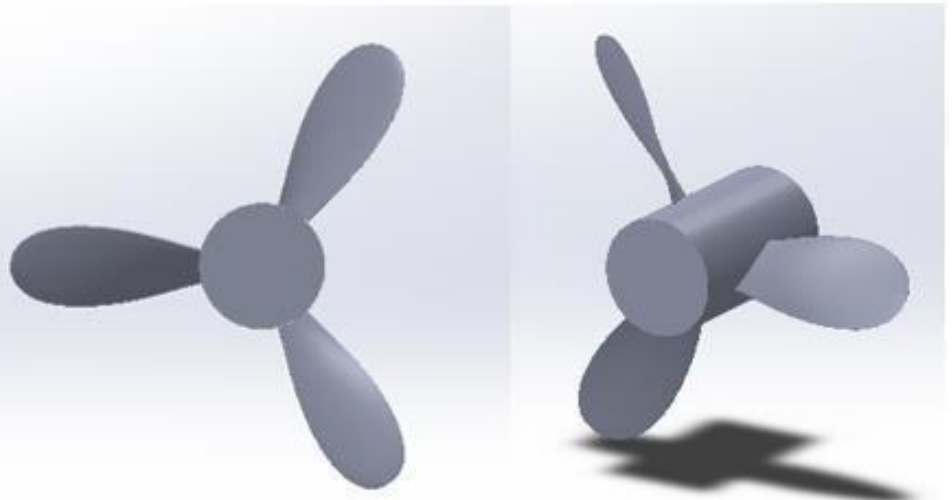

Figure. 6. Result of 3D modeling using Solidwork

4) Simulation Results Using CFDs

Then 3D modeling was done, for CFD simulation. Simulation results can be seen in table 2 .
With the discovery of thrust and torque values, KT and KQ values are searched with equations (1) and (2). The results of the search can be seen in Table 3 as follows:

TABLE 2.

RESULT OF CFD SIMULATION

\begin{tabular}{ccc}
\hline $\mathrm{J}$ & Thrust & Torque \\
\hline 0.2 & 1417.63 & 101.812 \\
0.4 & 1372.443 & 97.536 \\
0.6 & 1199.264 & 83.945 \\
0.8 & 990.444 & 70.244 \\
1 & 809.9511 & 59.96 \\
1.2 & 636.7874 & 50.567 \\
1.4 & 457.937 & 39.05 \\
\hline
\end{tabular}


International Journal of Marine Engineering Innovation and Research, Vol. 5(4), Dec. 2020. 216-223

TABLE 3.

RESULT OF KT AND 10KQ

\begin{tabular}{ccc}
\hline J & KT & $10 \mathrm{KQ}$ \\
\hline 12 & 0.4022 & 0.9027 \\
13 & 0.3894 & 0.8648 \\
14 & 0.3403 & 0.7443 \\
15 & 0.2810 & 0.6228 \\
16 & 0.2298 & 0.5317 \\
17 & 0.1807 & 0.4484 \\
1.4 & 0.1299 & 0.3462 \\
\hline
\end{tabular}

\section{OPEN WATER TEST CURVE (CFD)}

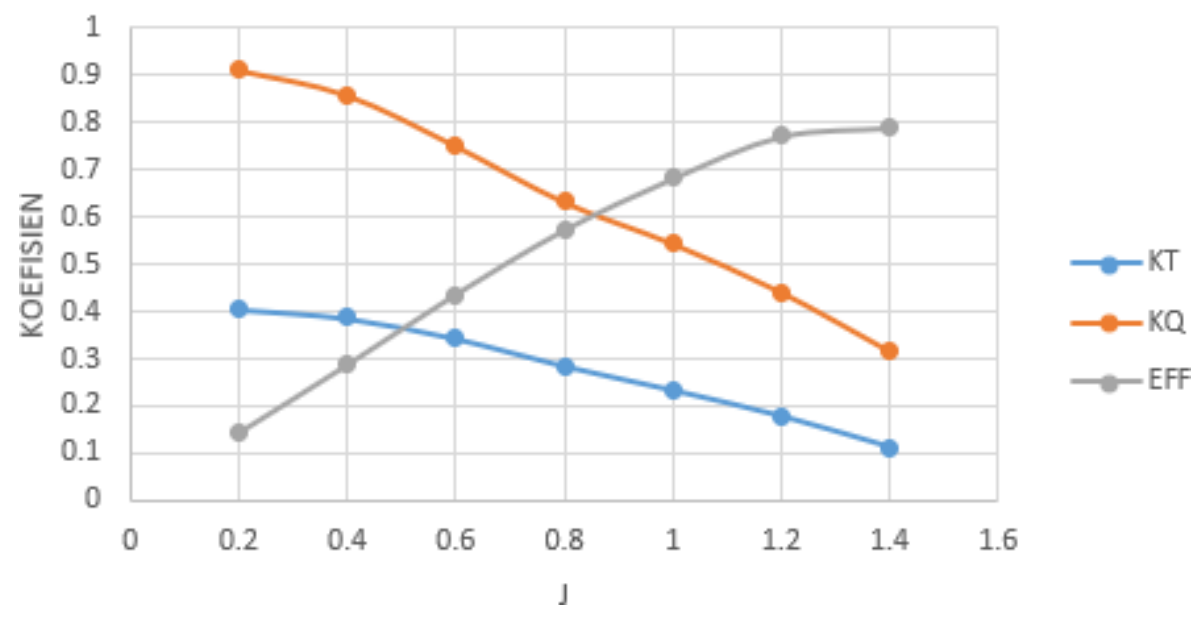

Figure. 7. Open water diagram using CFD

Figure 7 is an open water test diagram of the simulation results using CFDs. In table 2, the largest Thrust produced was $1417.63 \mathrm{~N}$ at $\mathrm{J}=0.2$. the resulting efficiency is 0.84 in $\mathrm{J}=1.4$.

\section{5) Model Validation}

Model validation is performed to see if the model used is valid. Here's the data propeller that will be validated:

$$
\begin{array}{ll}
\text { Propeller Diameter } & =0.32 \mathrm{~m} \\
\text { Blade } & =3 \text { Blade }
\end{array}
$$

Here is a comparison of calculation results using Openprop and CFDs as follows:

TABLE 4.

KT COMPARISON BETWEEN OPENPROP AND CFD

\begin{tabular}{cccc}
\hline $\mathrm{J}$ & $\begin{array}{c}\text { KT } \\
\text { Openprop }\end{array}$ & $\begin{array}{c}\text { KT } \\
\text { CFD }\end{array}$ & $\begin{array}{c}\text { SE } \\
(\%)\end{array}$ \\
\hline 0.2 & 0.2982 & 0.4022 & $5 \%$ \\
0.4 & 0.3029 & 0.3894 & $4 \%$ \\
0.6 & 0.3039 & 0.3403 & $2 \%$ \\
0.8 & 0.2891 & 0.2810 & $0 \%$ \\
1 & 0.2499 & 0.2298 & $1 \%$ \\
1.2 & 0.1964 & 0.1807 & $1 \%$ \\
1.4 & 0.13619 & 0.1299 & $0 \%$ \\
\hline
\end{tabular}


International Journal of Marine Engineering Innovation and Research, Vol. 5(4), Dec. 2020. 216-223

TABLE 5 .

10KQ COMPARISON BETWEEN OPENPROP AND CFD

\begin{tabular}{|c|c|c|c|}
\hline $\mathrm{J}$ & $\begin{array}{c}10 \mathrm{KQ} \\
\text { Openprop }\end{array}$ & $\begin{array}{c}10 \mathrm{KQ} \\
\mathrm{CFD} \\
\end{array}$ & $\begin{array}{l}\text { SE } \\
(\%) \\
\end{array}$ \\
\hline 0.2 & 0.66 & 0.9027 & $12 \%$ \\
\hline 0.4 & 0.6396 & 0.8648 & $11 \%$ \\
\hline 0.6 & 0.6235 & 0.7443 & $6 \%$ \\
\hline 0.8 & 0.6053 & 0.6228 & $1 \%$ \\
\hline 1 & 0.5548 & 0.5317 & $1 \%$ \\
\hline 1.2 & 0.4742 & 0.4484 & $1 \%$ \\
\hline 1.4 & 0.36711 & 0.3462 & $1 \%$ \\
\hline \multicolumn{4}{|c|}{$\begin{array}{l}\text { TABLE } 6 . \\
\text { ISON BETWEEN OPENPROP AND CFD }\end{array}$} \\
\hline $\mathrm{J}$ & $\begin{array}{l}\text { Efficiency } \\
\text { Openprop }\end{array}$ & $\begin{array}{l}\text { Efficiency } \\
\text { CFD }\end{array}$ & $\begin{array}{l}\mathrm{SE} \\
(\%)\end{array}$ \\
\hline 0.2 & 0.14389 & 0.14 & $0 \%$ \\
\hline 0.4 & 0.30164 & 0.29 & $1 \%$ \\
\hline 0.6 & 0.46568 & 0.44 & $1 \%$ \\
\hline 0.8 & 0.60843 & 0.57 & $2 \%$ \\
\hline 1 & 0.71725 & 0.69 & $1 \%$ \\
\hline 1.2 & 0.79141 & 0.77 & $1 \%$ \\
\hline 1.4 & 0.82702 & 0.84 & $0 \%$ \\
\hline
\end{tabular}

\section{6) Comparison Result of Simulation}

To find out the characteristics of each model, an Open Water Test chart comparison is made, In figure 8, it can be analyzed that the difference in KT values of Openprop and KT results of simulation has a larger difference in $\mathbf{J}=0.2$ which is 0.1040 . because the propeller is designed at $\mathrm{J}=1.4$, the difference value is 0.0063 . At $\mathrm{J}=0.2$ approaching $\mathrm{J}=0.6$, the Thrust value generated by the CFD simulation is greater than the result that Openprop obtains. The comparison of results can be seen in the Table below

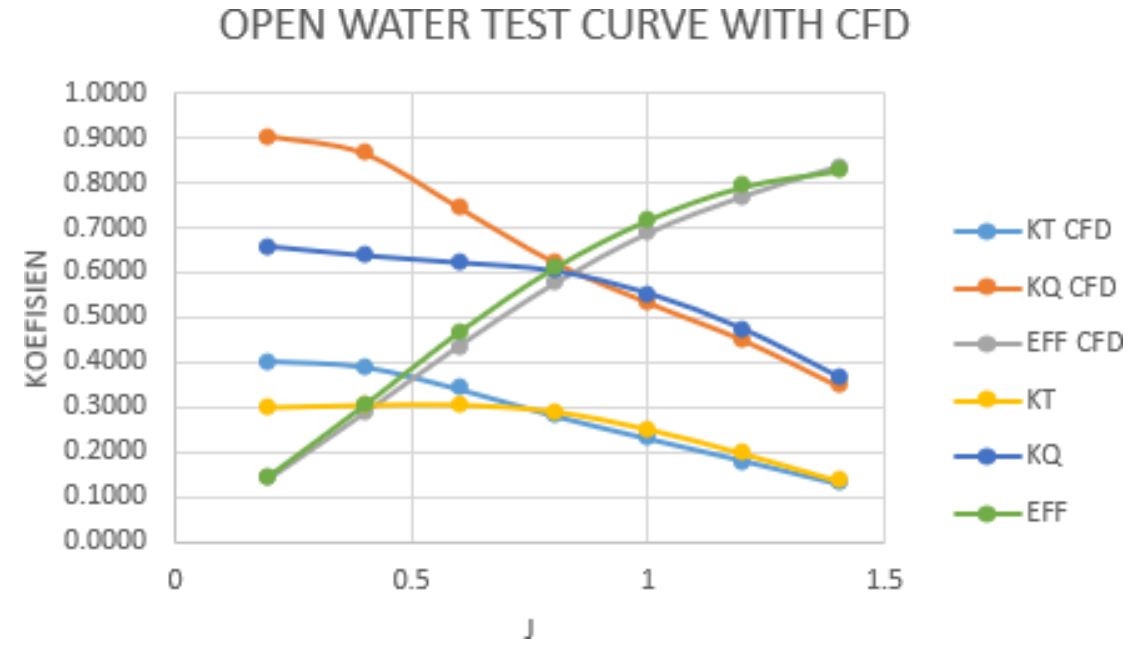

Figure. 8. Comparison open water diagram between CFD and Openprop 
TABLE 7.

THRUST COMPARISON BETWEEN OPENPROP AND CFD

\begin{tabular}{ccc}
\hline $\mathrm{J}$ & $\begin{array}{c}\text { Thrust } \\
\text { Openprop }(\mathrm{N})\end{array}$ & Thrust \\
$\mathrm{CFD}(\mathrm{N})$
\end{tabular}

In the comparison of KQ values, the largest difference in value at $J=0.2$ is 0.2427 while the smallest difference in value at $\mathbf{J}=0.8$, which is 0.0175 . same as the Thrust value, at $\mathbf{J}=0.2$ the torque value of the CFD result is greater than the calculation. The torque value comparison results can be seen in Table 8 .
In comparison to the propeller efficiency value, the value generated by both simulations is quite large. The efficiency of using Openprop is 0.82 , while using CFD simulation yields an efficiency value of 0.84 , having a difference of 0.02 .

TABLE 8. TORQUE COMPARISON OPENPROP AND CFD

\begin{tabular}{ccc}
\hline $\mathrm{J}$ & $\begin{array}{c}\text { Torque } \\
\text { Openprop }(\mathrm{N})\end{array}$ & $\begin{array}{c}\text { Torque } \\
\text { CFD }(\mathrm{N})\end{array}$ \\
\hline 0.2 & 74.4 & 101.812 \\
0.4 & 72.1 & 97.536 \\
0.6 & 70.3 & 83.945 \\
0.8 & 68.3 & 70.244 \\
1 & 62.6 & 59.96 \\
1.2 & 53.5 & 50.567 \\
1.4 & 41.4 & 39.05 \\
\hline
\end{tabular}

\section{CONCLUSION}

The conclusions in the results of this study are based on the author's initial goal of knowing the characteristic of symmetrical blade propeller is. Therefore, from the simulation results that have been done, it can be concluded:

1. Designing propeller design using numerical calculation is expected to be able to drive Jalapatih 3 ships at its operational speed. However, after CFD simulation, this propeller design has not been able to provide thrust value for the operational speed of Jalapatih 3 ship at a speed of 16 knots.

2. The difference in thrust value in $\mathbf{J}=1.4$ is $22,063 \mathrm{~N}$ while torque value has a difference of $2.35 \mathrm{Nm}$.

\section{REFERENCES}

[1] Carlton J.S,"Marine Propeller and Propulsion Second Edition, Elsevier Ltd, USA, 2010.

[2] Kuiper G,'The Wageningen Propeller Series," Marin Publication, USA, 1992

[3] Brien.T.P.O,"The Design of Marine Screw Propellers," Hutchinson \& CO Ltd, London, 1969

[4] Epps, B.P,’OpenProp v2.4 Theory Document," 2010.

[5] Mahadika, E.K,"Analysis Of Propeller Performance Type C4-40 with Various Distribution Pitch Propeller Using CFD," skripsi, Department of Marine Engineering, Faculty of Marine Technology, Institut Teknologi Sepuluh Nopember, Surabaya, 2019.

[6] Indiaryanto. M,’Uji Hidrodinamika dan Kajian Numerik Pengembangan Symmetrical Blade Propeller Untuk Kapal Patroli 60m dengan Menggunakan Teori Lifting Line, Journal Teknik ITS vol. 2, Departemen Teknik Sistem Perkapalan, Institut Teknologi Sepuluh Nopember, Surabaya, 2017. 